Article

\title{
The Formation of Dunite Channels within Harzburgite in the Wadi Tayin Massif, Oman Ophiolite: Insights from Compositional Variability of Cr-Spinel and Olivine in Holes BA1B and BA3A, Oman Drilling Project
}

\author{
Giuseppe Cocomazzi ${ }^{1}$, Giovanni Grieco $\left.{ }^{1, *} \mathbb{(}\right)$, Paola Tartarotti ${ }^{1}\left(\mathbb{D}\right.$, Micol Bussolesi $^{1}{ }^{1}$, \\ Federica Zaccarini ${ }^{2}$, Laura Crispini ${ }^{3}$ (D) and Oman Drilling Project Science Team ${ }^{\dagger}$ \\ 1 Department of Earth Sciences, Università degli Studi di Milano, via Mangiagalli 34, 20133 Milan, Italy; \\ giuseppe.cocomazzi@studenti.unimi.it (G.C.); paola.tartarotti@unimi.it (P.T.); \\ micol.bussolesi@unimi.it (M.B.) \\ 2 Department of Applied Geological Sciences and Geophysics, University of Leoben, A-8700 Leoben, Austria; \\ federica.zaccarini@unileoben.ac.at \\ 3 Dipartimento di Scienze della Terra dell'Ambiente e della Vita (DISTAV), University of Genova, Corso \\ Europa, 26, I-16132 Genova, Italy; laura.crispini@unige.it \\ * Correspondence: giovanni.grieco@unimi.it; Tel.: +39-02-5031-5629 \\ + Oman Drilling Project Science Team: https://www.omandrilling.ac.uk.
}

Received: 23 December 2019; Accepted: 5 February 2020; Published: 13 February 2020

\begin{abstract}
Holes BA1B and BA3A were drilled into the Wadi Tayin Massif, southern ophiolite complex of Oman, a fragment of the Tethyan oceanic lithosphere obducted onto the Arabian continent. Within the sequence, we have studied a portion of the shallow mantle, composed mainly of strongly serpentinised harzburgite that embeds dunitic levels, the biggest being over $150 \mathrm{~m}$ thick. The formation of thick dunitic channels, already approached via published structural and mathematical models, is here investigated with a mineral chemistry approach. We focused on Cr-spinel, the only widespread phase preserved during serpentinization, whose $\mathrm{TiO}_{2}$ content displays a wide variability from low in harzburgite, $\left(\mathrm{TiO}_{2}<0.25 \mathrm{wt}\right.$. \%), typical of non-metasomatised ophiolite mantle, to moderately high in dunite $\left(\mathrm{TiO}_{2}<1.10 \mathrm{wt}\right.$. \%) characterizing a rock/melt interactions. The high variability of $\mathrm{TiO}_{2}$, accompanied by similar patterns of $\mathrm{Cr} \#$ and $\mathrm{Mg} \#$ is observed, in a fractal pattern, at all scales of investigation, from the whole channel scale to the single thin section, where it affects even single grain zonings. Our results suggest that the over $150 \mathrm{~m}$ thick dunite channel here investigated was formed by coalescence of different scale melt channels and reaction zones with different sizes, confirming the published structural model.
\end{abstract}

Keywords: Oman Drilling Project; harzburgite; dunite channel; rock/melt reaction

\section{Introduction}

The study area is of great interest, as it is occupied by one of the most complete and best-preserved ophiolite sequences in the world: the Semail ophiolite complex, a group of several massifs cropping out in a NW-SE trending and $500 \mathrm{~km}$ long belt along the coast of Oman (Figure 1). The sampled cores come from two holes (700 $\mathrm{m}$ total length) drilled within the OmanDP program (e.g., http: //www.omandrilling.ac.uk/). A series of 15 continental drillings were performed within the Wadi Tayin Massif (or Ibra, Oman) in order to get a collection of cores that covers the full crustal and mantle sequence of the ophiolite. Two main lithologies characterize the 17 studied samples, harzburgite and 
dunite. In the cores, harzburgite and dunite occur as alternate levels of various thickness, intruded at places by minor gabbroic and pyroxenitic dykes. The whole rock-system is altered to a massive and pervasive extent, with a degree of serpentinization ranging from $85 \%$ to $100 \%$. A particularly relevant feature of the drilled ophiolitic sequence is the presence of thick dunitic levels within the harzburgitic mantle rocks, such as the one located at the top of the Hole BA1B, with an apparent thickness of over $160 \mathrm{~m}$. These dunitic levels are interpreted as channels resulting from melt (mid ocean ridge basalt, MORB) percolation through the upper mantle in an ocean ridge geodynamic environment $[1,2]$. Various hypotheses have been suggested for their formation. Among these, the most outstanding model opts for an initial phase of peridotite impregnation by a basaltic melt, occurring at the grain boundary scale [3-6]. The observation of an invariant power scale relationship between channel cumulative width and abundance, measured on four orders of magnitude, would justify the formation of channels up to hundreds of meters wide by coalescence of smaller channels and/or by the growing of their reaction zones [1].

The dunites we studied are linked to a process of percolation of basaltic melt in the upper mantle. In agreement with models reported by Braun and Kelemen [1], the percolation process can produce other types of dunite: a first dunite is due to melting of pyroxenes caused by melt/rock reaction; a second dunite is produced by fractional crystallization from the same percolating melt. The harzburgitic mantle in the Oman ophiolite contains dunites, either in the form of centimetric levels, or in the form of channels of relevant thickness. The observed dimensions have a range up to $10^{2} \mathrm{~m}$ and theoretically they can reach a thickness of $10^{3} \mathrm{~m}[1]$.

This study is aimed at finding clues of the channel network through the investigation of the primary mineralogical phases, within the dunite first, and then in harzburgites, as a term of comparison. The analysed minerals are olivine and $\mathrm{Cr}$-spinel, phases commonly used as petrogenetic indicators. The originality of the work is in testing the Braun and Kelemen model, in particular on the behavior of Cr-spinel, investigating its microchemical variations as a key to understand the process of melt-rock interaction which transformed harzburgite into dunite.

\section{Geological Setting}

The Semail ophiolite, to which the Wadi Tayin Massif belongs, represents a fragment of the Tethyan oceanic lithosphere obducted onto the Arabian continent and is the largest, best exposed and most studied ophiolite complex in the world (e.g., [7-10]). It was emplaced at least $200 \mathrm{~km}$ over the Arabian passive margin running parallel to the coastline of Oman extending in a NW-SE direction and exceeding $600 \mathrm{~km}$ in length and $75-130 \mathrm{~km}$ in width. The ophiolite complex origin is still controversial in terms of tectonic setting, i.e., a mid-ocean ridge origin (e.g., [2]) vs. a supra-subduction zone origin (e.g., $[10,11])$. Most structural and tectonic models proposed for the emplacement of the ophiolite and underlying thrust sheets suggest a NE-directed subduction away from the passive continental margin of the Arabian plate (e.g., [12]).

The Wadi Tayin massif (i.e., the study area, Figure 1) consists of an extensive mantle section overlain by a $5-7 \mathrm{~km}$ thick crustal gabbro section and a nearly continuous layer of dikes and pillow lavas (e.g., $[13,14])$. The mantle sequence mainly comprises harzburgite and dunite with dikes of gabbros and pyroxenites (e.g., [2,10]). A comprehensive field and chemical study of the dikes cropping out on the Oman harzburgite support the evidence of two groups of dikes: the first group derives from MORB-like melts (less abundant and restricted to the Wadi Tayin Massif); the second group derives from melts with characteristics closer to depleted andesites (mostly concentrated in the northern-central part of the Oman ophiolite [15]. Lherzolite is discontinuously distributed along the basal part of the mantle sequence $[16,17]$. The base of the sequence consists of up to $500 \mathrm{~m}$ of mylonitised peridotites (Banded Unit), which are underlain by a meta-sedimentary unit (metamorphic sole) [10]. Radiometric dating of plagiogranite and dating of radiolarian fauna from the pelagic sediments indicate that the crustal sequence of the Semail ophiolite has mid-Cretaceous ages (about $95 \mathrm{Ma}$ ) [18,19]. 
The mantle section of the Wadi Tayin is composed of residual harzburgite and minor lherzolite that host 5-15\% discordant dunite [13]. In the Wadi Tayin Massif, some lavas have trace element characteristics that are identical to those of MORB ([20] and references therein), whereas others lie just outside the MORB field on discriminant plots [21,22].

The harzburgites are residues of partial melting and melt extraction and are geochemically similar to the more depleted end of the abyssal peridotite compositional spectrum [5,13,16,23-25].

The dunites within the mantle section occur as tabular veins and sheets with sharp contacts with the host rock; they range in width from $51 \mathrm{~cm}$ to $100 \mathrm{~m}$ or more [1,26], and represent chemically isolated channels of focused melt percolated through the harzburgites. Dunites were formed by melt-rock reaction between MORB-like melts and harzburgite (e.g., [1,22,26]).
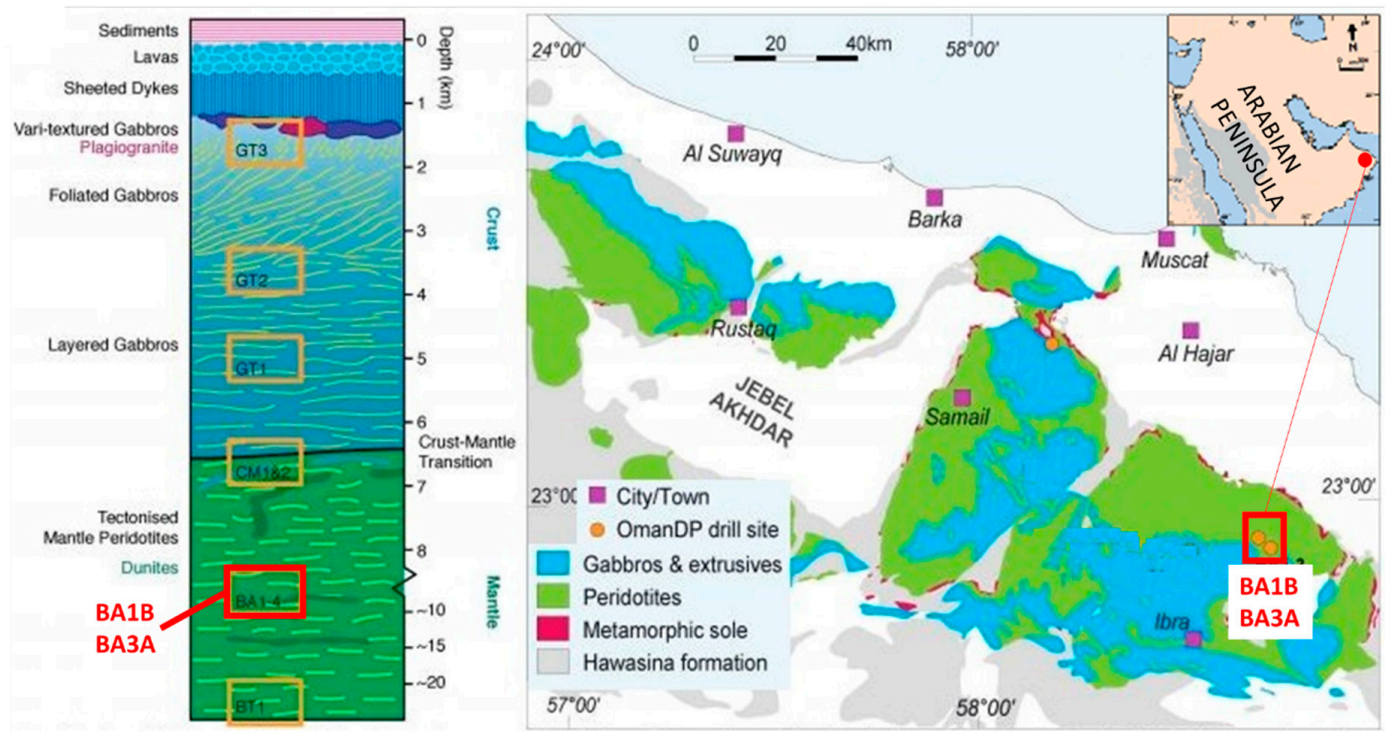

Figure 1. Geological map of Wadi Tayin massif of the Semail ophiolite showing the OmanDP drill site locations and their relative stratigraphic positions in a reconstructed stratigraphic log (modified from [27]). The red box indicates the area of BA1B and BA3A drill sites.

\section{Analytical Methods}

A total of 208 analyses were collected, 166 on Cr-spinel and 42 on olivine. Sample analyses include major and minor elements of Cr-spinel and olivine, carried out on 17 thin sections, 11 from Hole BA1B and six from Hole BA3A (Figure 2).

Microchemical analyses were performed on two different sets of samples by using two different electron microprobes (EMPs) with a carbon-coating used as electrical conductor. For samples ODP 0, 1, 2, 3, 4, 5, 6, 8, 9, 12 and 17A, a JXA-8200 Super Probe, located at the Earth Science Department "A. Desio" of the Milano University (Milan, Italy), was used. The operating conditions were set as follows: $15 \mathrm{kV}$ of acceleration voltage on the tungsten filament and $5 \mathrm{nA}$ of current electron beam with a point analysis of $1 \mu \mathrm{m}$ to $2 \mu \mathrm{m}$ of diameter (circa $3 \mathrm{~min}$ per analysis point). The standards used were: Na on omphacite, $\mathrm{Mg}$ on forsterite, Al-Si-Ca on grossular, Ti on ilmenite, Mn on rhodonite, Fe on fayalite, $\mathrm{K}$ on K-feldspar, $\mathrm{Cr}$ on metallic/pure $\mathrm{Cr}$ and $\mathrm{Ni}$ on niccolite. The wavelength-dispersive spectroscopy (WDS) used standards are: TAP (for Na, Mg, Al, Si), PET-J (for Ti, Cr), LIFH (for Mn, Fe, Ni) and PETH (for $\mathrm{K}$ and $\mathrm{Ca}$ ). For the elemental maps the operating conditions were the same of the EMP analyses.

For samples ODP 14, 18, 19C, 22, 24A and 26, a JXA-8200 Super Probe, located at the Earth Science Department "Montanuniversitat Leoben" (Austria), was employed. The operating conditions were set as follows: $15 \mathrm{kV}$ of acceleration voltage on the tungsten filament and $1 \mathrm{nA}$ of current electron beam with a point analysis of $1 \mu \mathrm{m}$ of diameter. The standards used were: $\mathrm{Na}-\mathrm{K}$ on sanidine, $\mathrm{Mg}$ on forsterite, Al on corundum, Si-Ca on diopside, Ti on rutile, Mn on rhodochrosite, Fe on almandine, 
Cr on Cr-spinel, Ni on skutterudite and Zn sphalerite. The WDS spectometers used were: TAP (for $\mathrm{Na}, \mathrm{Mg}, \mathrm{Al}$ ), PET-J (for Si, Ti), LIFH (for Cr, Mn, Fe, Ni) and PETH (for K and Ca). Detection limit are the same for both EMP and are as follows: approximately $330 \mathrm{ppm}$ for $\mathrm{Ti}$ (6\% standard deviation), $460 \mathrm{ppm}$ for Mn (6\% standard deviation), 160 ppm for Mg (2\% standard deviation), $180 \mathrm{ppm}$ for Si (6\% standard deviation), 370 ppm for Fe (8\% standard deviation), 140 ppm for Ca (15\% standard deviation), 135 ppm for $\mathrm{Al}$ (4\% standard deviation), 370 ppm for $\mathrm{Cr}$ (10\% standard deviation), $390 \mathrm{ppm}$ for $\mathrm{Ni}$ (9\% standard deviation) and 800 ppm for $\mathrm{Zn}$ (9\% standard deviation). $\mathrm{Fe}^{3+}$ was recalculated from microprobe analyses assuming perfect stoichiometry of the minerals, based on the 8-oxygen formula. Fo is determined as percentage of olivine ratio-cations, $\mathrm{Fo}=100 \times \mathrm{Mg} /\left(\mathrm{Mg}+\mathrm{Fe}^{2+}+\mathrm{Mn}+\mathrm{Ca}\right)$.
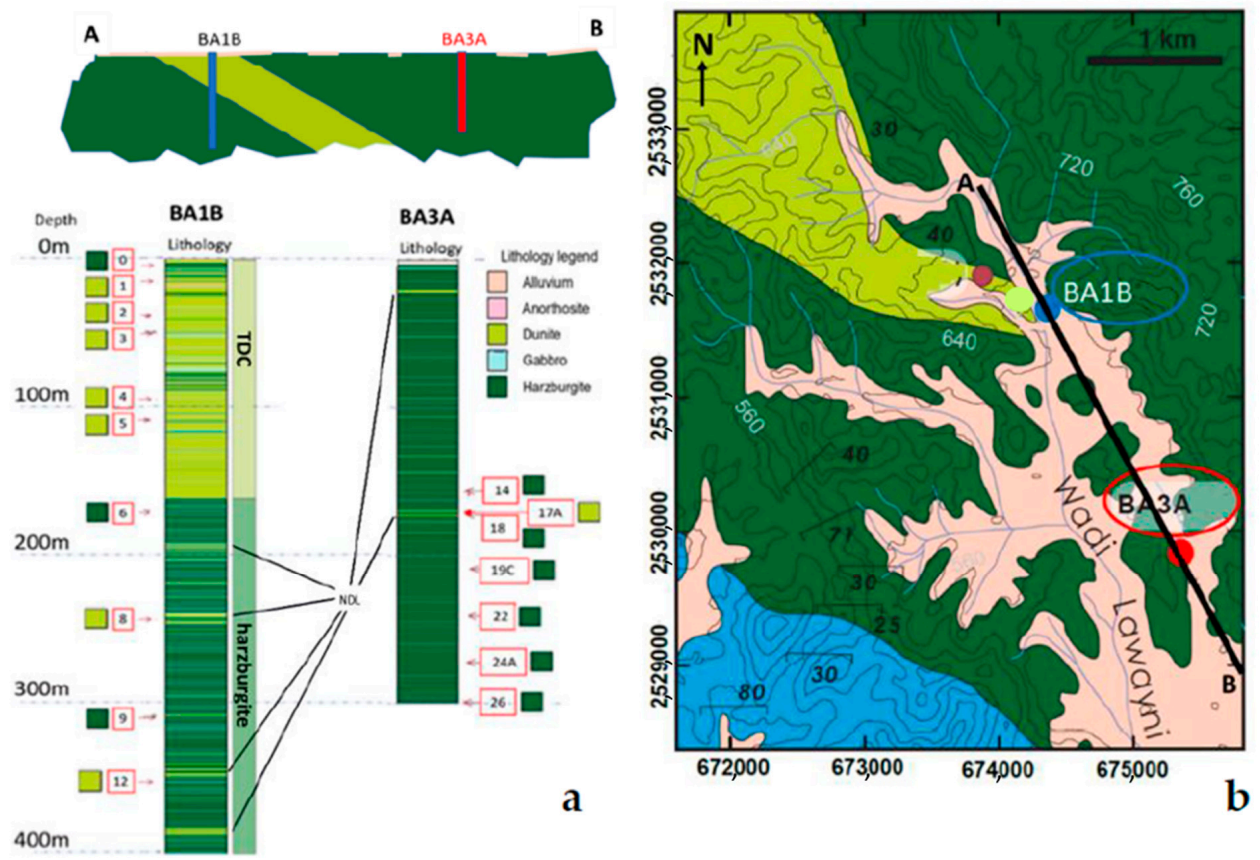

Figure 2. (a) Modelled geological section along the black line $A B$ of Figure $2 b$, with the position of BA1B and BA3A Holes, their respective stratigraphic columns with samples position and relative thin section number in the red boxes. (b) Geological map of the drilling area (modified by after [28]).

For the samples analysed in Austria, raw data show correct proportion of cations as atoms per formula units (a.p.f.u.), in spite of the low total wt. \% (from less to much less of $100 \mathrm{wt}$ \%). For this reason, recalculation of the structured formula performed after normalizing the oxide wt. \% to 100 , as shown in the Supplementary Materials (Tables S1-S8).

Points for analyses were selected on grayscale, back-scattered electron (BSE) images. The major and minor elements for minerals are routinely reported as wt. \% of the oxides.

\section{Texture and Mineral Chemistry}

We have analysed olivine and Cr-spinel crystals in dunite and harzburgite, as petrogenetic indicators of melt evolution or melt-rock interaction. The analysed rocks pertain to three domains (see Figure 2): 1. harzburgite (hereafter "harz") representing the host rock of dunite; 2 . thick dunite channel (hereafter TDC, overall $>100 \mathrm{~m}$ ); 3. narrow dunite layer (hereafter NDL, $<50 \mathrm{~cm}$ ). All these lithologies are strongly serpentinised, from $85 \%$ to $100 \%$.

The whole serpentinised sequence does not preserve the primary silicate assemblage, with the exception of minor olivine relics and rare pyroxenes. Ferrian-chromitization of primary spinel is not widespread and, where present, affects only spinel rims.

The mineral chemistry of olivine relics and unaltered spinels provides the most reliable clue to unravel the formation of large dunite channels. In some samples we can recognize only rare relics of 
olivine at the core of strongly serpentinised grains. Not all samples bear these relics, thus, while fresh Cr-spinel occurs in all thin sections, fresh olivine crystals suitable for chemical analyses are limited to a few thin sections.

\subsection{Texture}

Cr-spinel crystals in both lithologies have a shape ranging from rare vermicular (Figure 3a,f) to mainly holly leaf (Figure 3b-e), sometimes roundish (Figure 3g), irregular (Figure 3h) or subheudral (Figure 3i) with grain size ranging between 0.5 and $3.0 \mathrm{~mm}$. All these shapes are interpreted as deriving from a peridotite with a fabric ranging from protogranular to porphiroclastic and equigranular [29]. Disseminated Cr-spinel crystals within dunite and harzburgite are mainly dispersed in a serpentine matrix, or more rarely in altered pyroxene relics or in contact with fresh olivine relics ( $3 c)$. Olivine was the major silicate constituent, but at present it occurs as individual polygonal to irregular relict crystal fragments that belong to the same crystal domain, as inferred from the same interference color (Figure 3c). Other minor constituents of the serpentine matrix are orthopyroxene (Figure 3f), rare clinopyroxene, amphibole and chlorite. Serpentinization is pervasive and altered almost completely all silicates but did not affect the Cr-spinel grains.
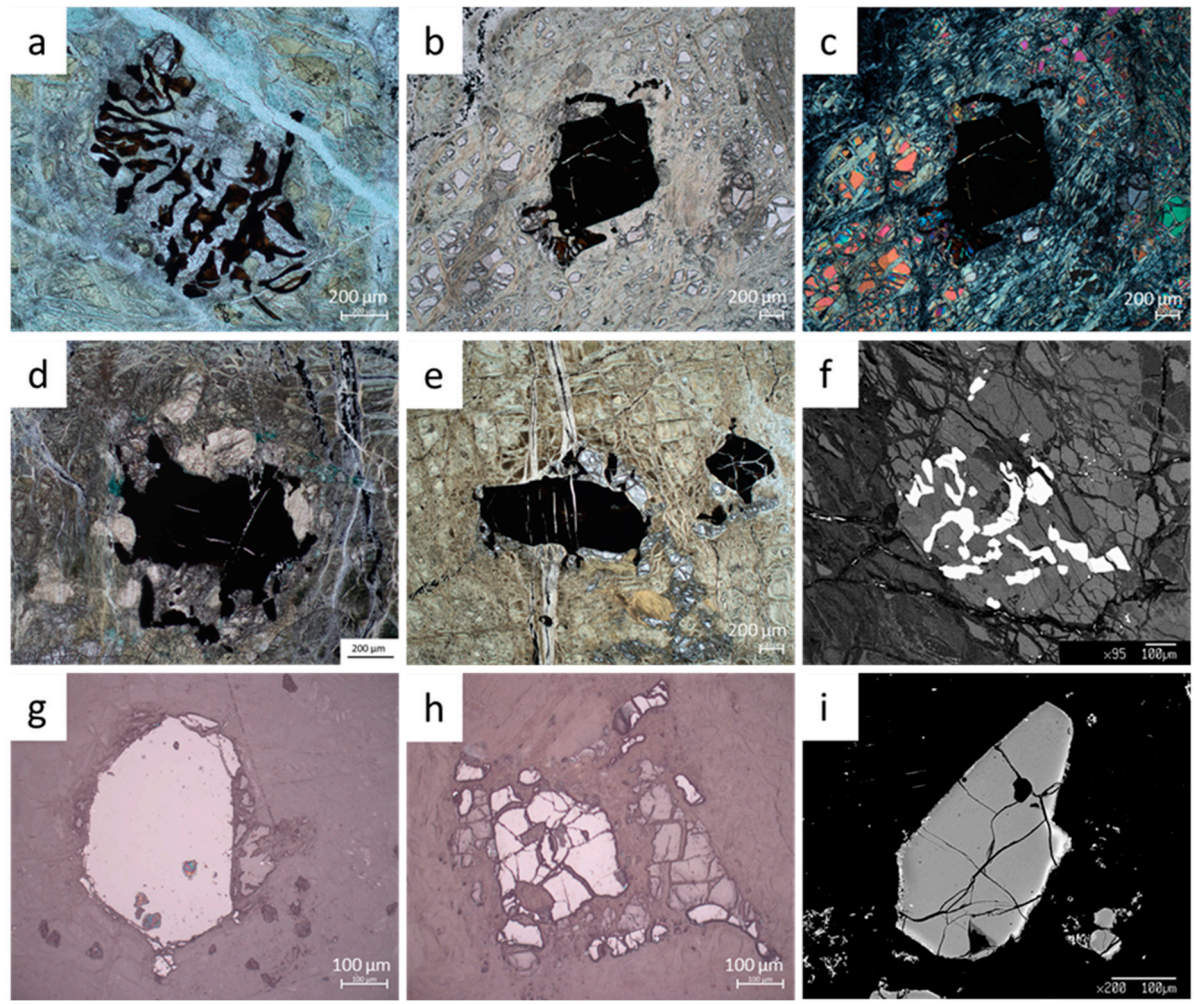

Figure 3. Cr-spinels from Hole BA1B, by optical microscope in Transmitted Light (TL), Reflected Light (RL) and by scanning electron microscope (SEM) in backscattered electrons (BSE). Number of thin section and magnification are reported. (a) TS_11_TL_10x, Cr-spinel grain with vermicular shape (1N); (b) TS_9_TL_5x, harzburgite, Cr-spinel grain with holly leaf shape and locally vermicular (1N); (c) TS_9_TL_5x, as image b (2N), fragments of fresh olivine, with the same high interference colors, are visible; (d) TS_8_TL_10x, dunite, Cr-spinel grain with holly leaf shape (1N); (e) TS_12_TL_5x, dunite, disseminated Cr-spinel crystals with holly leaf shape (1N); (f) TS_9_SEM, harzburgite, BSE image of Cr-spinel grain with vermicular shape included in pyroxene; (g) TS_2_RL_20x, dunite, euhedral crystal of Cr-spinel; (h) TS_0_RL_20x, harzburgite, irregular fractured Cr-spinel grain; (i) TS_0_SEM, harzburgite, BSE image of Cr-spinel crystal with magnetite or ferritchromite on the edge. 


\subsection{Cr-Spinel Mineral Chemistry}

Cr-spinel shows a wide range of compositions covering the fields from $\mathrm{Cr}$-spinel to ferritchromite. However, ferritchromite analyses (Table S6) were not considered in this study because the serpentinization is a later low temperature alteration process not studied here. The compositional variations in terms of major oxides (wt. \%) and cation numbers of $99 \mathrm{Cr}$-spinel cores were distinguished by lithology. Cr-spinel within harzburgite is on average slightly higher in $\mathrm{Cr}_{2} \mathrm{O}_{3}$ (36.9-50.2 wt. \%) compared to Cr-spinel in dunite (32.0-48.8 wt. \%), while an opposite trend occurs for $\mathrm{TiO}_{2}$ content with higher values in dunite $(<1.00 \mathrm{wt}$. \%) and lower values in Cr-spinel in harzburgite $(<0.42 \mathrm{wt} . \%)$. Other oxides record a similar range of values with $\mathrm{Al}_{2} \mathrm{O}_{3}$ (13.3-31.1 wt. \%), $\mathrm{Fe}_{2} \mathrm{O}_{3}$ (3.2-13.5 wt. \%), $\mathrm{FeO}\left(17.0-24.0\right.$ wt. \%) and $\mathrm{MgO}$ (6.9-12.5 wt. \%) for Cr-spinel in dunite and $\mathrm{Al}_{2} \mathrm{O}_{3}$ (15.6-27.4 wt. \%), $\mathrm{Fe}_{2} \mathrm{O}_{3}$ (1.3-10.4 wt. \%), $\mathrm{FeO}$ (16.6-23.3 wt. \%) and $\mathrm{MgO}$ (7.7-12.5 wt. \%) for Cr-spinel in harzburgite. Both TDC and NDL show wide ranges of chemical composition (see $\S 5.1$ ).

For 55 grains of $\mathrm{Cr}$-spinel we have compared the $\mathrm{TiO}_{2}$ content of the cores to that of the respective rims by calculating a delta value $(\Delta)$ by subtracting the core value from the rim value (see Table 1 ). Dunite has the higher variability of delta $\mathrm{TiO}_{2}$ (from -0.66 to $0.33 \mathrm{wt}$. \%) compared to delta $\mathrm{TiO}_{2}$ in harzburgite (from -0.09 to 0.04 wt. \%).

Table 1. Representative electron microprobe analyses of selected element oxides and ratio-cations number for Cr-spinel crystals from all dunite and harzburgite samples; ranging value of max, $\min$, average, standard deviation and delta value (rim minus core) are also shown. Complete dataset is available in the supplementary materials.

\begin{tabular}{|c|c|c|c|c|c|c|c|c|c|c|c|c|c|}
\hline & & & $\mathrm{MgO}$ & $\mathrm{Fe}_{2} \mathrm{O}_{3}$ & $\mathrm{FeO}$ & $\mathrm{Cr}_{2} \mathrm{O}_{3}$ & $\mathrm{Al}_{2} \mathrm{O}_{3}$ & $\mathrm{TiO}_{2}$ & $\mathrm{NiO}$ & Mg\# & Cr\# & $\mathrm{Fe}^{3+} \#$ & $\mathrm{Al} \#$ \\
\hline \multirow{8}{*}{$\begin{array}{l}\stackrel{0}{\Xi} \\
\Xi \\
\end{array}$} & \multirow{4}{*}{$\begin{array}{l}\text { chromite } \\
\text { core }\end{array}$} & $\min$ & 6.86 & 3.23 & 17.02 & 31.99 & 13.29 & 0.00 & 0.05 & 0.34 & 0.41 & 0.04 & 0.26 \\
\hline & & $\max$ & 12.54 & 13.51 & 24.02 & 48.82 & 31.09 & 1.00 & 0.26 & 0.57 & 0.68 & 0.17 & 0.55 \\
\hline & & avg & 9.71 & 8.12 & 21.08 & 39.91 & 21.70 & 0.47 & 0.13 & 0.45 & 0.55 & 0.10 & 0.40 \\
\hline & & $\begin{array}{c}\text { st } \\
\mathrm{dev}\end{array}$ & 1.48 & 2.65 & 1.88 & 3.63 & 3.71 & 0.27 & 0.05 & 0.06 & 0.06 & 0.03 & 0.06 \\
\hline & \multirow{4}{*}{$\begin{array}{c}\Delta \\
\text { rim-core }\end{array}$} & $\min$ & -2.92 & -4.38 & -0.61 & -4.97 & -7.31 & -0.66 & -0.14 & -0.12 & -0.09 & -0.05 & -0.12 \\
\hline & & $\max$ & 0.80 & 4.52 & 3.28 & 10.82 & 5.01 & 0.33 & 0.12 & 0.03 & 0.13 & 0.06 & 0.09 \\
\hline & & avg & -1.00 & 0.62 & 1.35 & -0.19 & -0.79 & -0.02 & -0.01 & -0.04 & 0.01 & 0.01 & -0.01 \\
\hline & & $\begin{array}{c}\text { st } \\
\mathrm{dev}\end{array}$ & 1.04 & 1.58 & 1.18 & 3.55 & 3.40 & 0.22 & 0.07 & 0.04 & 0.06 & 0.02 & 0.06 \\
\hline \multirow{8}{*}{ 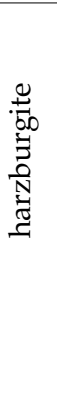 } & \multirow{4}{*}{$\begin{array}{l}\text { chromite } \\
\text { core }\end{array}$} & $\min$ & 7.68 & 1.27 & 16.60 & 36.89 & 15.64 & 0.00 & 0.01 & 0.37 & 0.48 & 0.01 & 0.30 \\
\hline & & $\max$ & 12.52 & 10.38 & 23.33 & 50.19 & 27.38 & 0.42 & 0.19 & 0.56 & 0.68 & 0.12 & 0.49 \\
\hline & & avg & 10.26 & 5.55 & 19.57 & 44.35 & 20.41 & 0.09 & 0.09 & 0.48 & 0.59 & 0.07 & 0.38 \\
\hline & & $\begin{array}{c}\text { st } \\
\mathrm{dev}\end{array}$ & 0.94 & 1.85 & 1.42 & 3.65 & 2.57 & 0.10 & 0.04 & 0.04 & 0.05 & 0.02 & 0.04 \\
\hline & \multirow{4}{*}{$\begin{array}{c}\Delta \\
\text { rim-core }\end{array}$} & $\min$ & -3.02 & -1.71 & -1.23 & -5.10 & -1.01 & -0.09 & -0.08 & -0.13 & -0.09 & -0.02 & -0.01 \\
\hline & & $\max$ & 1.24 & 3.23 & 4.09 & 0.62 & 5.75 & 0.04 & 0.12 & 0.04 & 0.02 & 0.04 & 0.09 \\
\hline & & avg & 0.20 & 0.04 & -0.02 & -2.05 & 1.84 & -0.01 & 0.02 & 0.00 & -0.02 & 0.00 & 0.03 \\
\hline & & $\begin{array}{c}\text { st } \\
\mathrm{dev}\end{array}$ & 0.82 & 1.12 & 1.02 & 1.63 & 1.65 & 0.04 & 0.05 & 0.03 & 0.03 & 0.01 & 0.03 \\
\hline
\end{tabular}

In Table 1 a brief summary of some Cr-spinel oxides is reported, together with cation numbers, respectively, for core and delta values, distinguished by lithology.

Figure 4 shows the correlation of selected oxides and cations numbers for Cr-spinel crystal cores. 

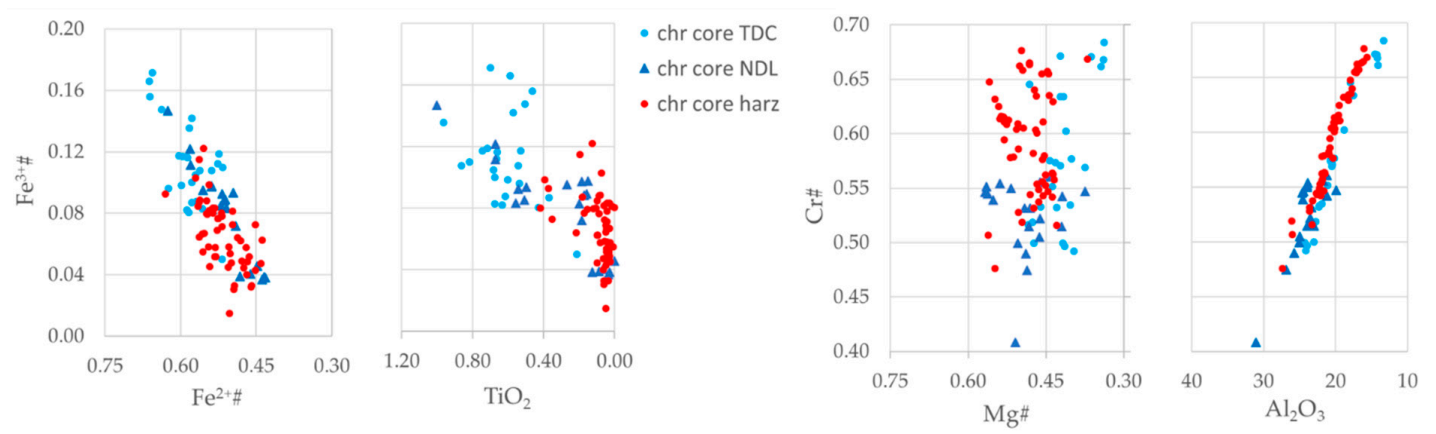

Figure 4. Diagram $\mathrm{Fe}^{2+} \#$ vs $\mathrm{Fe}^{3+} \#, \mathrm{TiO}_{2}$ wt. \% vs $\mathrm{Fe}^{3+} \#, \mathrm{Mg} \#$ vs $\mathrm{Cr} \#$ and $\mathrm{Al}_{2} \mathrm{O}_{3}$ wt. \% vs Cr\# on Cr-spinel-core for TDC, NDL and harzburgite.

\subsection{Olivine Mineral Chemistry}

Due to serpentinization, several thin sections (seven out of 17) totally lack relics of fresh olivine. In the remaining samples, fragments of olivine are clearly visible, some of which can be traced back to the same crystalline domain, (extinction and interference colors vary simultaneously). Olivine fragments have a maximum size of few tens of micrometers.

The variation ranges of major oxides (wt. \%) and the Fo-number in the 42 analysed fresh fragments were distinguished by lithology and reported in Table 2 (the complete EMP analyses are reported in the supplementary files). The Fo content of olivine is slightly lower in dunite (88.6-89.1) compared to olivine in harzburgite (89.1-90.4). $\mathrm{Ni}$ is the most abundant trace element in olivine. In dunite, olivine has slightly lower Ni values (0.24-0.40 wt. \%) than in harzburgite $(0.28-0.44$ wt. \%).

Table 2. Representative analyses of olivine from dunite and harzburgite with max, min and average ranging value of olivine for some oxides and Fo number in BA1B and BA3A Holes.

\begin{tabular}{lcccccccc}
\hline Lithology & & $\mathrm{SiO}_{2}$ & $\mathbf{M g O}$ & $\mathbf{F e O}$ & $\mathrm{NiO}$ & $\mathrm{CaO}$ & $\mathrm{MnO}$ & Fo \\
\hline \multirow{4}{*}{ dunite } & $\min$ & 40.49 & 48.44 & 10.39 & 0.24 & 0.01 & 0.11 & 88.63 \\
& $\max$ & 41.15 & 49.00 & 10.95 & 0.40 & 0.04 & 0.21 & 89.11 \\
& avg & 40.78 & 48.66 & 10.70 & 0.34 & 0.02 & 0.16 & 88.84 \\
& st dev & 0.17 & 0.18 & 0.20 & 0.04 & 0.01 & 0.03 & 0.16 \\
\hline \multirow{5}{*}{ harzburgite } & $\min$ & 36.82 & 48.64 & 9.26 & 0.28 & 0.00 & 0.07 & 89.13 \\
& $\max$ & 41.40 & 51.53 & 10.77 & 0.44 & 0.06 & 0.17 & 90.41 \\
& avg & 39.78 & 50.26 & 9.94 & 0.35 & 0.02 & 0.13 & 89.84 \\
& st dev & 1.37 & 0.87 & 0.40 & 0.04 & 0.02 & 0.03 & 0.38 \\
\hline
\end{tabular}

\section{Discussion}

\subsection{Cr-Spinel}

Cr-spinel turned out to be the most important phase preserving primary features. The composition of $\mathrm{Cr}$-spinel cores in harzburgite and dunite differs mainly in $\mathrm{TiO}_{2}$ content. $\mathrm{TiO}_{2}$ content is recognised as a useful marker to investigate rock/melt reaction processes; it displays a wide variability from low $\mathrm{TiO}_{2}$ contents in Cr-spinel from harzburgites ( $<0.25 \mathrm{wt}$. \%) [30], typical of non-metasomatised ophiolite mantle, to elevated $\mathrm{TiO}_{2}$ contents in Cr-spinel from dunites ( $>0.25 \mathrm{wt}$. \%)[30], indicative of metasomatism by rock/melt reaction ([30-34] and references therein). Figure 5 shows the distribution pattern of $\mathrm{TiO}_{2}$ content versus $\mathrm{Cr} \#$ and $\mathrm{Mg} \#$ for Cr-spinel from harzburgites and dunites (TDC and NDL). Cr-spinel (ether rims or cores) $\mathrm{TiO}_{2}$ contents of TDC and harzburgite plot almost completely in distinguished areas, i.e., in metasomatised and not-metasomatised fields, respectively. The only four outliers (Ti-rich Cr-spinels in harzburgite) refer to a thin harzburgite layer in dunite and to the main harzburgite body close to the contact with TDC. NDL Cr-spinel, on the contrary, shows a distribution that overlaps both the metasomatised and not-metasomatised fields. Cr\# and Mg\# are 
less discriminating, showing partial overlapping compositional fields for $\mathrm{Cr}$-spinel in harzburgite and dunite (TDC and NDL) (Figure 5).

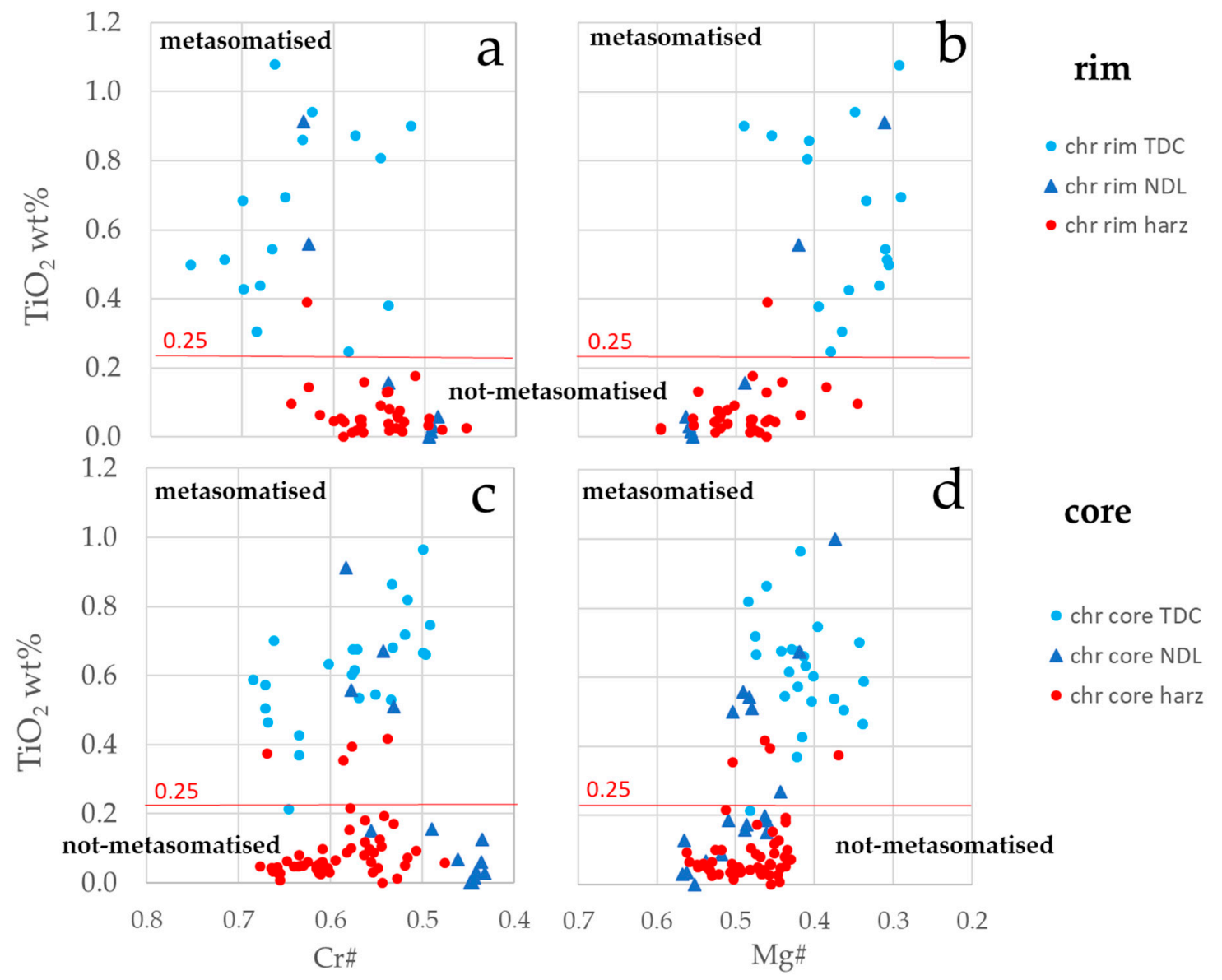

Figure 5. $\mathrm{TiO}_{2}$ wt. \% plotted against $\mathrm{Cr} \#(\mathbf{a}, \mathbf{c})$ and $\mathrm{Mg \#}(\mathbf{b}, \mathbf{d})$, for rim $(\mathbf{a}, \mathbf{b})$ and core $(\mathbf{c}, \mathbf{d})$ in $\mathrm{Cr}$-spinel from analysed rocks. Metasomatised and not-metasomatised $\mathrm{Cr}$-spinel are defined on the basis of $\mathrm{TiO}_{2}$ wt. $\%=0.25$ (modified after $[29,30]$ and the references therein).

In order to identify a chemical evolution of $\mathrm{Cr}$-spinels, the core to rim variations of $\mathrm{Cr} \#$ and $\mathrm{TiO}_{2}$ were compared (Figure 6).

In harzburgite, both $\mathrm{TiO}_{2}$ contents and rim-core $\Delta \mathrm{TiO}_{2}$ values show a low variability (Figures 5 and 6 ). The former is restricted to the $<0.25 \mathrm{wt}$. \% field and the latter shows a maximum of 0.09 wt. \% in absolute terms within the same $\mathrm{Cr}$-spinel crystal. The low variability of $\Delta \mathrm{TiO}_{2}$, coupled with a low variability of $\Delta \mathrm{Cr} \#$ in $\mathrm{Cr}$-spinel hosted in harzburgite suggests that no event disturbed this equilibrium.

Within TDC, Cr-spinel shows a scattered distribution of $\Delta \mathrm{TiO}_{2}$. All rim-core pairs show a $\mathrm{TiO}_{2}$ content higher than $0.20 \mathrm{wt}$. \%. Among them, 30\% have a $\mathrm{TiO}_{2}$ variability between rim and core higher than absolute value $|0.20|$ wt. $\%$, with the highest variabilities being -0.66 and 0.33 wt. \%. It should finally be noted that uneven distribution of Ti occurs either among different thin sections or within a single section, in terms of both $\mathrm{TiO}_{2}$ and $\Delta \mathrm{TiO}_{2} . \Delta \mathrm{Cr} \#$ variability is the highest within TDC (from -0.09 to 0.13 ), even though the $\mathrm{Cr} \#$ variation is significantly lower with respect to $\Delta \mathrm{TiO}_{2}$.

The $\Delta \mathrm{TiO}_{2}$ and $\Delta \mathrm{Cr} \#$ values in NDL Cr-spinels show a distribution intermediate between TDC and harzburgite, being confined between -0.25 and $0.25 \mathrm{wt}$. \%, and -0.07 and $0.05 \mathrm{wt}$. \%, respectively. 


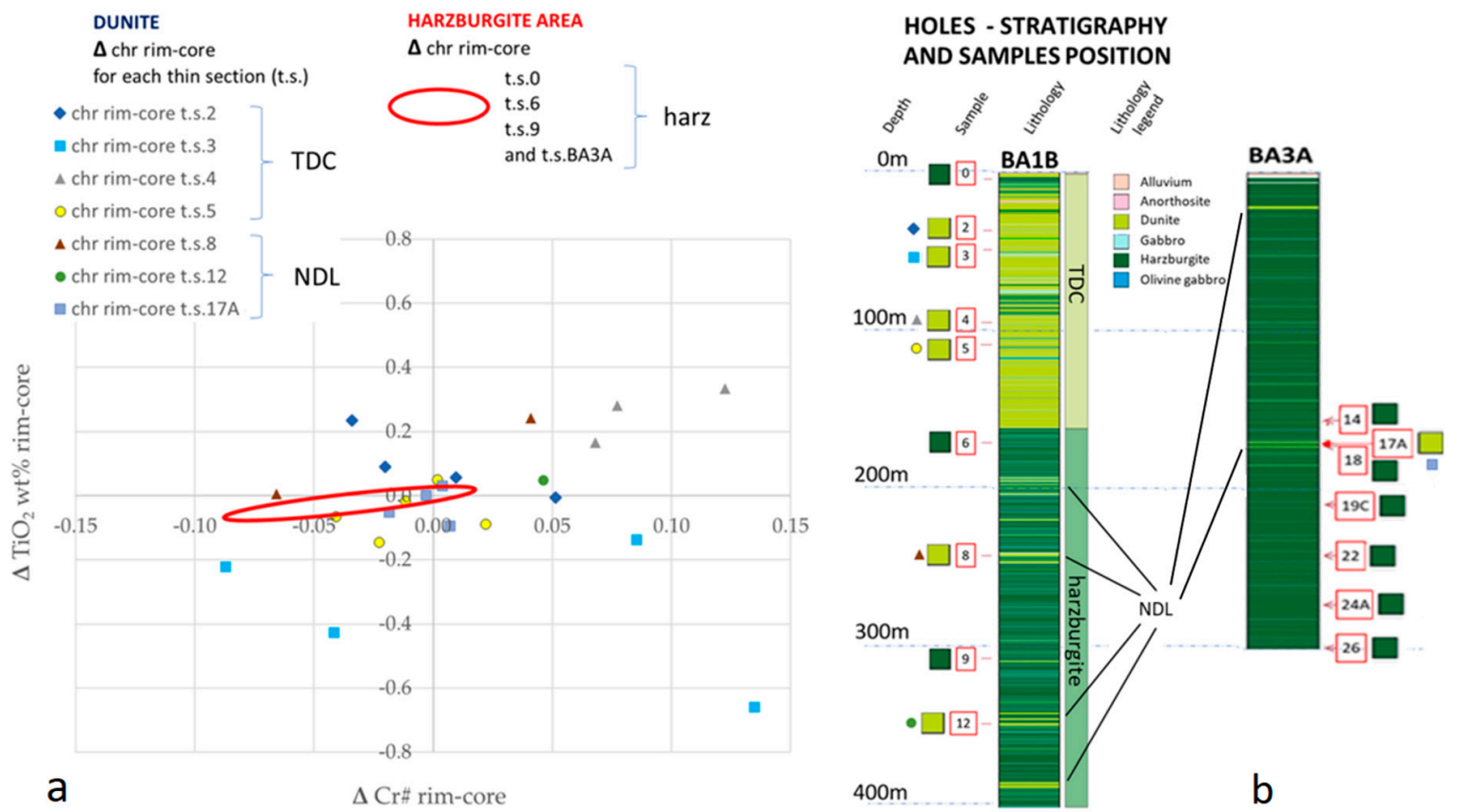

Figure 6. (a) $\mathrm{Cr} \#$ vs $\mathrm{TiO}_{2}$ diagram, expressed as $\Delta \mathrm{TiO}_{2}$ and $\Delta \mathrm{Cr} \#$ (i.e., as the difference between the rim and the core composition) in each $\mathrm{Cr}$-spinel grain analysed in dunite. The red circle delimits the compositional field of analysed Cr-spinels in harzburgite (t.s. 0,6,9 and t.s. from BA3A), not shown as plotted points. (b) BA1B and BA3A stratigraphic columns with samples position (number in red squared and lithology on the side) [28].

In the Braun and Kelemen [1] model on the percolation of a basaltic melt through a residual harzburgitic mantle, the residual peridotite reacts with the melt. We expect that the interaction between a MORB enriched in $\mathrm{Ti}[35,36]$ and a $\mathrm{Cr}$-spinel produces a Ti-rich $\mathrm{Cr}$-spinel. The analysed $\mathrm{Cr}$-spinels show a heterogeneous enrichment in $\mathrm{TiO}_{2}$. The high variability in $\mathrm{TiO}_{2}$ content of $\mathrm{Cr}$-spinel in TDC suggests that basaltic melt/Cr-spinel reaction was extremely scattered and resulted in the crystallization of new Ti-rich Cr-spinel and/or in the incomplete re-equilibration of the original Cr-spinel grains. Similar variable compositions were observed in the outcropping Wadi Tayin dunites [20]. Highly variable $\mathrm{TiO}_{2}$ content in NDL Cr-spinels was found as well.

Core-rim zoning in TDC Cr-spinels does not follow any regular pattern: negative and positive $\Delta \mathrm{TiO}_{2}$ zonings coexist at different scales from the whole thickness of the channel down to different zonings within the same $\mathrm{Cr}$-spinel grain (Figure 7). The coexistence of such different zonings within the same grains is evident in EMP element maps (Figure 7), where $\Delta \mathrm{TiO}_{2}$ is too small to be visible, but it can be clearly seen for variation in $\mathrm{Cr}, \mathrm{Al}, \mathrm{Mg}$ and $\mathrm{Fe}$ contents. In particular, elemental maps of $\mathrm{Cr}$ and $\mathrm{Al}$ highlight different zonings at the rim of the grain that cannot possibly be related to sub-solidus exchange with the silicate phase in contact. This result suggests that the MORB infiltrated through fractures and came into contact with different parts of the same spinel crystal.

The extreme variability of melt-rock interaction indicated by the variable $\mathrm{TiO}_{2}, \mathrm{Cr} \#$ and $\Delta \mathrm{TiO}_{2}$ in NDL Cr-spinels rules out the possibility that at any time the rock hosted a thick batch of magma, whose differentiation would have produced more regular compositional trends in spinel. On the contrary, it seems to suggest a multi-stage (partial?) re-equilibration with different magma batches, as indicated in particular by grains with a negative $\Delta \mathrm{TiO}_{2}$. Analogue melt percolation processes have been postulated for interpreting the dunites in the MTZ of the Sumail Massif [37,38]. The presence of both positive and negative $\Delta \mathrm{TiO}_{2}$ from the grain to the metric scale can be explained in the frame of a fractal distribution of melt channels impregnating the rock giving rise to a complex network of differently evolved melts. 

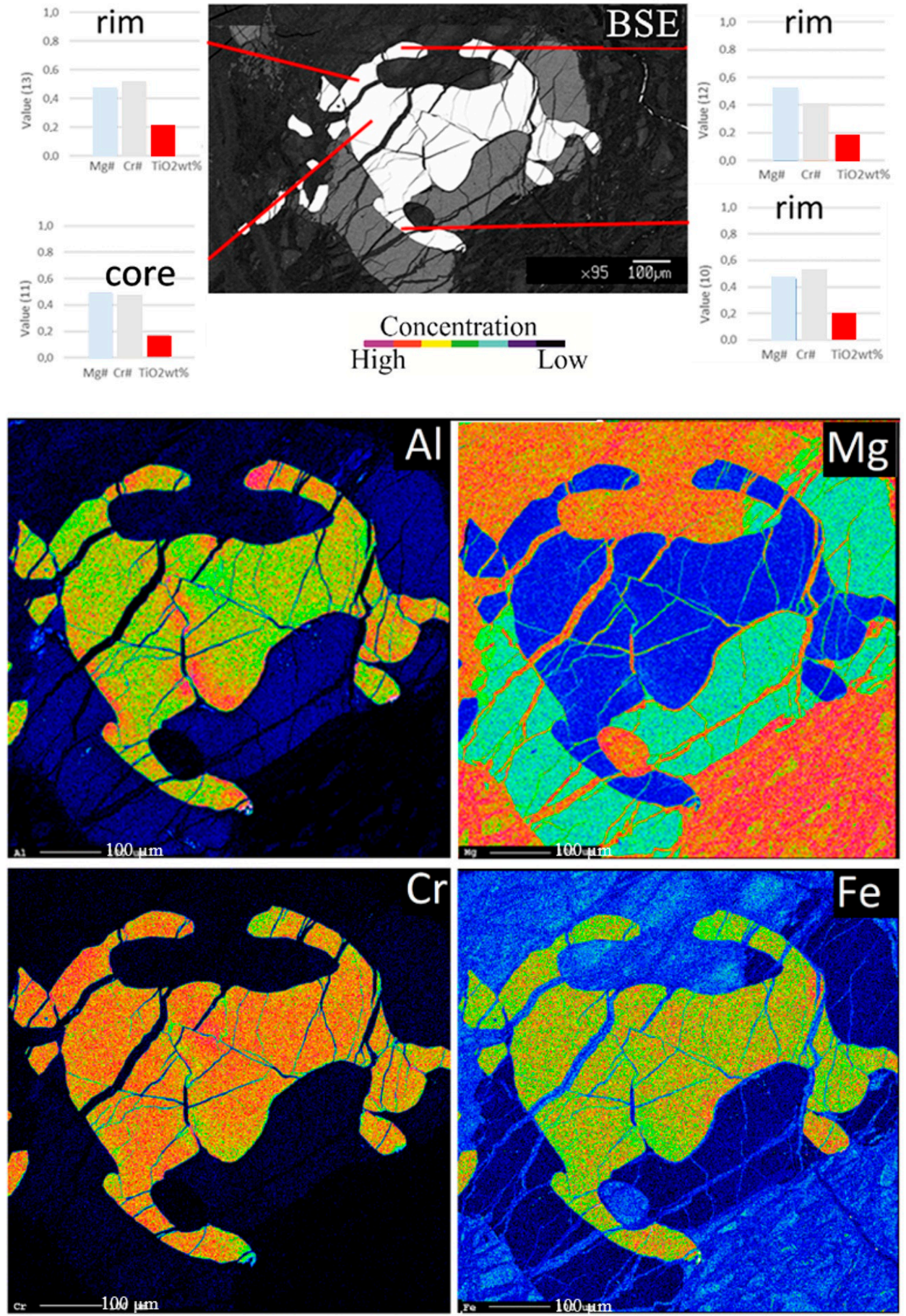

Figure 7. BA1B Hole. BSE images and X-ray elemental maps. This crystal of Cr-spinel shows a higher concentration of $\mathrm{Al}$ along an internal fracture, to which corresponds a depletion of $\mathrm{Fe}_{\text {tot }}$ and $\mathrm{Cr}$, compared to the core of the same grain. Meanwhile, the point analyses show a nearly constant amount of $\mathrm{TiO}_{2}$.

\subsection{Olivine}

Numerical modeling of the behavior of the major elements (namely $\mathrm{Mg}, \mathrm{Fe}$ ) and trace elements $(\mathrm{Ni}, \mathrm{Sc}, \mathrm{Nd})$ during the formation of dunite from harzburgite by the dissolution-precipitation reaction shows that for a given Fo value of olivine in dunite, both the amount of olivine precipitation and the initial Mg\# of a migrating melt are important [39,40]. 
The harzburgitic and dunitic olivine of this study show different Fo content (Figure 8a), with the dunitic olivine being characterised by systematically lower values $(\mathrm{Fo}=88.6-89.1)$ than the harzburgitic olivine (Fo $=89.1-90.4)$. Fo-poor olivine in dunite can be the result of the interaction between harzburgite and a differentiated basaltic melt with a fayalitic composition. The dunite formation is due to dissolution-precipitation reaction [39,40], whereby pyroxenes in harzburgite are dissolved and new olivine precipitates. In dunite, there is not a high variability in $\mathrm{Mg}$ content between metasomatic and magmatic olivine, suggesting a complete re-equilibration of both olivines, due to their high diffusion coefficient [34].

$\mathrm{Ni}$ content in olivines has been reported by different authors as being lower in dunites with respect to surrounding harzburgites [20,41]. Suhr et al. [40] noticed a relation between the olivine mineral chemistry and dunite thickness. As the thickness of the body increases, olivine assumes more restitic character, increasing its Fo content, while $\mathrm{NiO}$ variations do not seem to be affected by channel dimensions, as suggested by previous observation [40]. Analyses on olivine from both lithologies (Figure 8a) show comparable Ni contents, ranging between $\sim 0.25$ and $\sim 0.45$.
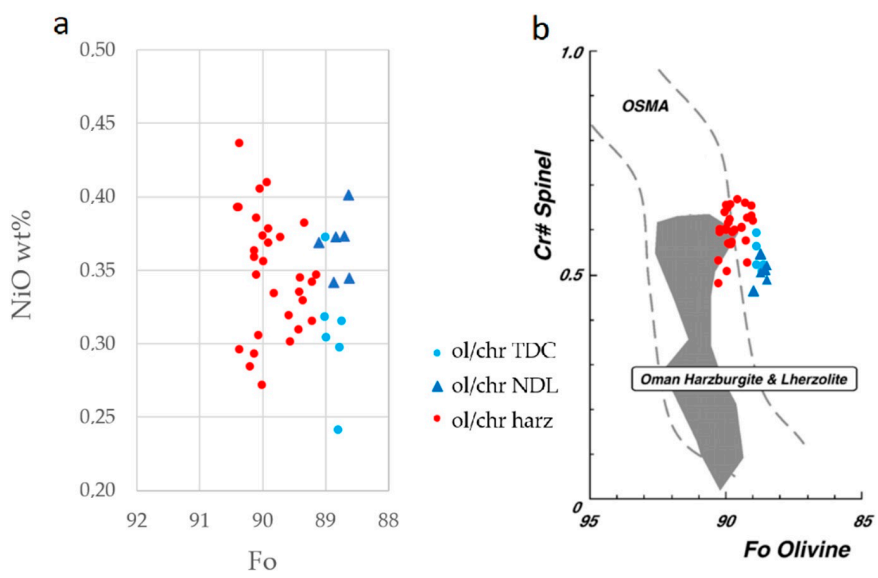

Figure 8. Binary diagrams: (a) $\mathrm{NiO}$ wt. \% vs Fo; (b) Cr\# vs. Fo, compositional relationship between Fo content of olivine and Cr\# of spinel in the harzburgite (red circle), TDC (light blue) and NDL (dark blue), in the Wadi Tayin massif, from Holes BA1B and BA3A Holes (this study). OSMA (olivine-spinel mantle array; [42,43]) is a spinel peridotite restite trend. Range of Oman harzburgite and lherzolite are from Kadoshima [44] and Takazawa et al. [17]. Light and dark blue circles for dunite, red for harzburgite.

Furthermore, it was observed [40] that the chemistry of the dunite-harzburgite sections varies as a function of dunite thickness. As the thickness of dunite bodies increases, the mineralogy of the dunite becomes more refractory with higher Fo in olivine and higher Cr\# in spinel.

The comparison of Cr\# vs Fo content of spinels and olivines from all lithologies (Figure 8b) allows to mark the difference between restitic harzburgite and metasomatised dunite. Chemical composition of Cr-spinel from harzburgites plots within the field of the Olivine Spinel Mantle Array (OSMA), in accordance to other studies [20] on the same area, while metasomatised dunites compositions fall outside of the OSMA field, i.e., towards a higher Fo content.

Olivine from the TDC has a similar range of Fo compositions (88.7-89.0) and lower $\mathrm{NiO}$ values are generally lower $(0.24-0.38 \mathrm{wt}$. \%) when compared to the NDL hosted in mantle harzburgites. This implies that olivine from the big channel and those from narrow levels recorded the same depletion. We have no comparisons with olivine from harzburgitic levels hosted in the TDC.

\subsection{Formation of $T D C$}

In Figure 9, we propose, by commented cartoons, a model for melt percolation into a peridotite upwelling under a mid ocean ridge [1], suggesting time by time what happens in a mineral chemistry perspective. The model, which explains the formation of the aforementioned TDC, is described at a 
centimetric scale, starting from the impregnation of a peridotite by a basaltic melt. The frame of the model is a mantle peridotite as attested by the texture of studied spinel crystals.

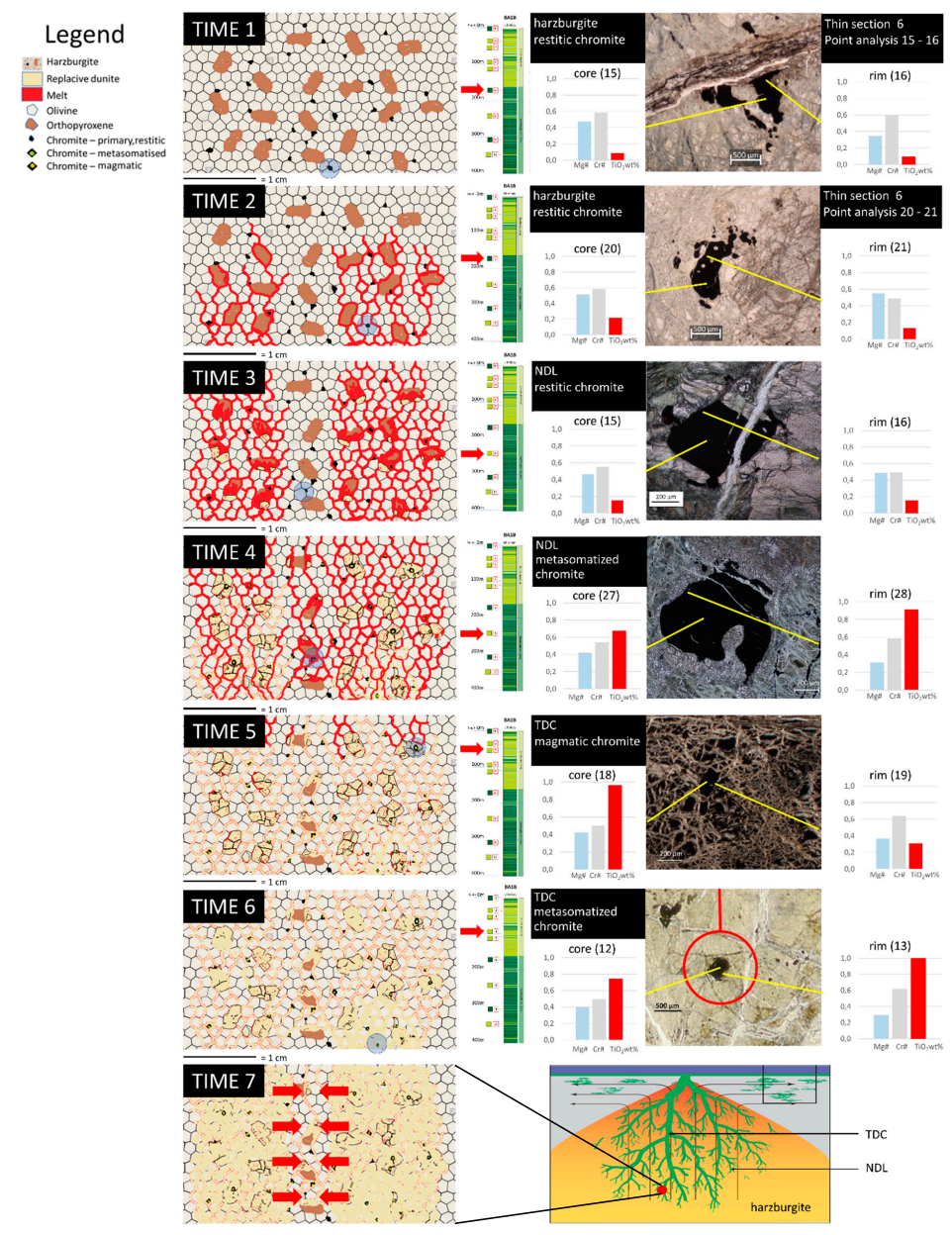

Figure 9. Conceptual model illustrating the chemical signature of the Cr-spinel during the evolution of harzburgite into dunite for studied samples. This evolution envisages the melt percolation through the mantle peridotite developed during seven stages (Time 1 to Time 7). For each Time that leads to the melt/rock interaction we associate optical microscopic images of a $\mathrm{Cr}$-spinel grains, its stratigraphic position (for details see Figure 2) and its EMP analyses with values of $\mathrm{Mg \# ,} \mathrm{Cr \#} \mathrm{and} \mathrm{TiO}_{2}$ wt. \%. Time 1-Harzburgite into the shallow mantle, composed by olivine (light poligons), orthopyroxene (brown) and $\mathrm{Cr}$-spinel (black). Primary $\mathrm{Cr}$-spinel is Ti-poor and there is no chemical zonation. Time 2-A basaltic melt intrudes the harzburgite, percolating along the grain boundaries of olivine, orthopyroxene and Cr-spinel. Cr-spinel grains may come and keep in contact with Ti-rich melt and little variation in $\mathrm{TiO}_{2}$ content can occur. Time 3-While the basaltic melt intrudes through the harzburgite, orthopyroxene melts and first grains of olivine crystallize. Unreacted $\mathrm{Cr}$-spinel preserves a low content of $\mathrm{TiO}_{2}$. Time 4-Orthopyroxenes are dissolved and substituted by magmatic olivine. New olivine runs to equilibrium with restitic olivine very fast. At the same time, very close (less than $2 \mathrm{~cm}$ ) to the unreacted Cr-spinel grain of Time 3, another Cr-spinel grain is completely plunged into the Ti-rich melt and reacts strongly recording very high contents of $\mathrm{TiO} 2$. Time 5-Magmatic olivine has crystallised within orthopyroxene sites and along grain boundaries. During the process of rock/melt reaction, also Ti-rich $\mathrm{Cr}$-spinel cores can be found and interpreted as new $\mathrm{Cr}$-spinel grains. Time 6-The flow of the basaltic melt, now disappeared, is replaced by a network of magmatic olivine that continues to react under subsolidus conditions, inducing metasomatic reactions in the restitic olivine. Time 7-Two dunitic channels, homogeneous in composition, run to merge forming a bigger channel. The red point/position in the fractal pattern dunite [modified after 1] is only an example, because the same process occurs on every area fluxed/impregnated by the melt and at multiple scale. 
This description is applicable to different scales. For each step (or "Time") that leads to the transformation of harzburgite into dunite, we associate optical microscopic images of a Cr-spinel grain, its stratigraphic position and its EMPA analyses with values of $\mathrm{Mg \# ,} \mathrm{Cr \#} \mathrm{and} \mathrm{TiO}_{2}$ wt. \%.

In this simplified representation we consider the harzburgite as the starting lithology, composed only by olivine, orthopyroxene and Ti-poor Cr-Spinel. We also assume that the studied harzburgite belongs to an intermediate to fast spreading oceanic center [1] in which orthopyroxenes are unstable under the new pressure conditions and the other minerals present, olivine and $\mathrm{Cr}$-spinel, are considered primary (Time 1). The composition of harzburgitic olivine is shown in Table 2, as well as the composition of the harzburgitic Cr-spinel cores is reported in Table 1.

During Time 2, the melt is strongly undersaturated with orthopyroxene under these pressure conditions [44] and rich in Ti as we defined before. A rising melt, due to its density lower than that of the host-rock, percolates through the harzburgite at intergranular level, exploiting the volumes of greater weakness of the wall-rock, according to the model [1,41]. These weak zones can be identified primarily with the intergranular porosity $[45,46]$ induced by melting of orthopyroxenes. Thus, more "vascularised" portions with high permeability developed within the rock. These portions can be assumed as protochannels of a focused porous flow of adiabatically ascending melt $[2-5,26,41,47]$. The focused porous flow can generate thick dunites, inside which the melts migrate, not contacting with the surrounding peridotites [2,41]. In the dunites $>1 \mathrm{~m}$ thick, the isolation of the melt is achieved by keeping the bulk of the melts beyond the distance of diffusive equilibration with the surrounding rocks. Thus, the melts ascending inside a high-porosity dunite channel are in equilibrium only with the dunite minerals $[2,26]$. The necessity of pyroxene dissolution in the process of dunite formation obviously contradicts the fact that most of oceanic basalts are strongly undersaturated with respect to orthopyroxene at low pressure. However, the contradiction is eliminated by the fact that the amount of melt reacting with pyroxenes to produce dunite is significantly lower than the melt flux moving inside the formed dunite channels to the surface and not participating in the reaction. This is quite possible if the melt transport is focused into the already formed dunite channels. The intruded melt reacts with all rock minerals, changing their composition in order to reach an equilibrium. $\mathrm{Cr}$-spinel can change its primary low $\mathrm{TiO}_{2}$ content due to reaction with $\mathrm{TiO}_{2}$-rich melts.

At Time 3, the melt increases its flow by exploiting the porosity produced and at the same time promoting the precipitation of new olivine into the space previously occupied by orthopyroxene, as well as along intergranular boundaries. Some primary $\mathrm{Cr}$-spinels, although belonging to developing channel, do not register any contact or reaction with the melt and maintain their low $\mathrm{TiO}_{2}$ content.

In the following stage (Time 4), the melt/rock interaction takes on relevant dimensions. All orthopyroxenes into the melting flow are dissolved and magmatic olivine takes its place. The primary olivine in contact with the melt and new olivine run to equilibrium very fast, not allowing a distinction between them [32]. Cr-spinel records sensitive changes in the $\mathrm{TiO}_{2}$ content. All spinels within the dunite have $\mathrm{TiO}_{2}$ values above the conventional $0.25 \mathrm{wt}$. \%, defined as the limit between not metasomatised Cr-spinels, which have not reacted with a melt (Time 3), and metasomatised Cr-spinels ([30,31] and references therein).

At Time 5 and 6 , the areas of rock affected by the flow of the melt now have a dunitic composition, with olivine homogeneous chemical composition (Table 2). The $\mathrm{TiO}_{2}$ content of the $\mathrm{Cr}$-spinel continues to record significant variations, between rim and core, either decreasing (Time 5) or increasing (Time 6).

Over time, the same process occurs on every area fluxed/impregnated by the melt and at multiple scale.

The coalescence of little channels and the merging of their reaction zones (by sub-solidus metasomatism), indicated by the red arrows at Time 7, produces channels with increasing size. Within them relict unaffected harzburgitic levels are recognizable for a different olivine Fo number and low $\mathrm{TiO}_{2}$ content in Cr-spinel. 


\section{Conclusions}

The mineral chemistry approach can provide an important contribution to the study of TDCs, providing information that can support the genetic model proposed in literature by Braun and Kelemen [1], where the $\sim 160 \mathrm{~m}$ thick dunite channel was formed by coalescence of different scale melt channels and their reaction zones.

The upward basaltic melt percolation in a MOR environment starts with intrusion of melt along weakness zones of a restitic harzburgite, mainly partially melted orthopyroxenes sites and intergranular boundaries. The long-lasting melt flow yields total dissolution of orthopyroxenes and complete re-equilibration of primary and new formed olivines. Cr-spinel, being the more refractory primary phase is the last one to record the metasomatic process of melt-rock interaction. In any case, the cores of Cr-spinels are at least partially re-equilibrated with the melt.

The results show that the high variability of the chemical parameters can be observed, in a fractal pattern, at all scales investigated, from the whole channel scale, tens of meters, to the intergranular scale within a single thin section, millimeters, where it affects even single grain zoning patterns.

Supplementary Materials: The following are available online at http://www.mdpi.com/2075-163X/10/2/167/s1, Tables S1-S8: Compositional tables of minerals analysed with the electron microprobe.

Author Contributions: Conceptualization, G.C., G.G. and P.T.; Methodology, G.C., G.G., F.Z., M.B.; Validation, P.T., F.Z. and L.C.; Formal Analysis, G.C. and F.Z.; Investigation, G.G., M.B. and G.C.; Resources, Oman Drilling Project Science Team, G.G. and P.T.; Data Curation, G.C. and M.B.; Writing-Original Draft Preparation, G.C and P.T..; Writing-Review and Editing, G.G., F.Z., L.C. and P.T.; Visualization, G.C.; Supervision, G.G., P.T. and M.B. All authors have read and agreed to the published version of the manuscript.

Funding: This research received no external funding.

Acknowledgments: This study has benefited from discussions with Fernando Camara Artigas and Giulio Borghini. Special thanks are due to Andrea Risplendente for technical assistance with the electron microprobe. This research used samples and/or data provided by the Oman Drilling Project. The Oman Drilling Project (OmanDP) has been possible through co-mingled funds from the International Continental Scientific Drilling Project (ICDP; Kelemen, Matter, Teagle Lead PIs), the Sloan Foundation-Deep Carbon Observatory (Grant 2014-3-01, Kelemen PI), the National Science Foundation (NSF-EAR-1516300, Kelemen lead PI), NASA-Astrobiology Institute (NNA15BB02A, Templeton PI), the German Research Foundation (DFG: KO 1723/21-1, Koepke PI), the Japanese Society for the Promotion of Science (JSPS no:16H06347, Michibayashi PI; and KAKENHI 16H02742, Takazawa PI), the European Research Council (Adv: no.669972; Jamveit PI), the Swiss National Science Foundation (SNF:20FI21_163073, Früh-Green PI), JAMSTEC, the TAMU-JR Science Operator and contributions from the Sultanate of Oman Ministry of Regional Municipalities and Water Resources, the Oman Public Authority of Mining, Sultan Qaboos University, CNRS-Univ. Montpellier, Columbia University of New York and the University of Southampton.

Conflicts of Interest: The authors declare no conflict of interest.

\section{References}

1. Braun, M.G.; Kelemen, P.B. Dunite distribution in the Oman Ophiolite: Implications for melt flux through porous dunite conduits: Dunite Distribution in the Oman Ophiolite. G-cubed 2002, 21, 1-21. [CrossRef]

2. Nicolas, A. Structure of Ophiolites and Dynamics of Oceanic Lithosphere; Kluwer Academic Publishers: Dordrecht, The Netherlands, 1989; p. 367.

3. Aharonov, E.; Whitehead, J.A.; Kelemen, P.B.; Spiegelman, M. Channeling instability of upwelling melt in the mantle. J. Geophys. Res. 1995, 100, 20433-20450. [CrossRef]

4. Kelemen, P.B.; Dick, H.J.B. Focused melt flow and localised deformation in the upper mantle: Juxtaposition of replacive dunite and ductile shear zones in the Josephine peridotite, SW Oregon. J. Geophys. Res. 1995, 100, 423-438. [CrossRef]

5. Kelemen, P.B.; Shimizu, N.; Salters, V.J.M. Extraction of midocean-ridge basalt from the upwelling mantle by focused flow of melt in dunite channels. Nature 1995, 375, 747-753. [CrossRef]

6. Spiegelman, M.; Kelemen, P.B.; Aharonov, E. Causes and consequences of flow organization during melt transport: The reaction infiltration instability in compactable media. J. Geophys. Res. Solid Earth 2001, 106, 2061-2077. [CrossRef]

7. Glennie, K.W.; Boeuf, M.G.A.; Clarke, M.W.H.; Moody-Stuart, M.; Pilaar, W.F.H.; Reinhardt, B.M. Late Cretaceous Nappes in Oman Mountains and Their Geologic Evolution. AAPG Bull. 1973, 57, 5-27. 
8. Glennie, K.W.; Boeuf, M.G.A.; Hughes Clarke, M.W.; Moody-Stuart, M.; Pilaar, W.F.H.; Reinhardt, B.M. Geology of the Oman Mountains. Verh. van het K. Ned. Geol. Mijnbouwkd. Genoot. 1974, 31, 432. [CrossRef]

9. Coleman, R.G. Tectonic setting for ophiolite obduction in Oman. JGR Space Phys. Solid Earth 1981, 86, 2497-2508. [CrossRef]

10. Lippard, S.J.; Shelton, A.W.; Gass, I.G. The Ophiolite of Northern Oman. Geol. Soc. Mem. Geol. Soc. Blackwell Sci. Publ. London 1986, 11, 178.

11. Alabaster, T.; Pearce, J.A.; Malpas, J. The volcanic stratigraphy and petrogenesis of the Oman ophiolite complex. Contrib. Mineral. Petrol. 1982, 81, 168-183. [CrossRef]

12. Searle, M.P.; Warren, C.J.; Waters, D.J.; Parrish, R.R. Subduction zone polarity in the Oman Mountains: Implications for ophiolite emplacement. In Ophiolites in Earth History; Dilek, Y., Robinson, P.T., Eds.; Geological Society, London, Special Publications: Bath, UK, 2003; Volume 218, pp. 467-480.

13. Boudier, F.; Coleman, R.G. Cross section through the peridotite in the Samail ophiolite, southeastern Oman mountains. J. Geophys. Res. 1981, 86, 2573-2592. [CrossRef]

14. Pallister, J.S.; Hopson, C.A. Semail ophiolite plutonic suite: Field relations, phase variation, cryptic variation and layering, and a model of a spreading ridge magma chamber. J. Geophys. Res. 1981, 86, 2593-2644. [CrossRef]

15. Python, M.; Ceuleneer, G. Nature and distribution of dykes and related melt migration structures in the mantle section of the Oman ophiolite. G-cubed 2003, 4, 7. [CrossRef]

16. Godard, M.; Jousselin, D.; Bodinier, J.L. Relationships between geochemistry and structure beneath a palaeo-spreading centre: A study of the mantle section in the Oman ophiolite. Earth Planet. Sci. Lett. 2000, 180, 133-148. [CrossRef]

17. Takazawa, E.; Okayasu, T.; Satoh, K. Geochemistry and origin of the basal lherzolites from the northern Oman Ophiolite (northern Fizh block). G-cubed 2003, 4. [CrossRef]

18. Rioux, M.; Bowring, S.; Kelemen, P.; Gordon, S.; Miller, R.; Dudas, F. Tectonic Development of theSamail Ophiolite: High-Precision U-Pb Zircon Geochronology andSm-Nd Isotopic Constraints on Crustal Growth and Emplacement. J. Geophys. Res. 2013, 118, 2085-2101. [CrossRef]

19. Tilton, G.R.; Hopson, C.A.; Wright, J.E. Uranium-lead isotopic ages of the Semail ophiolite, Oman, with applications to Tethyan ocean ridge tectonics. J. Geophys. Res. 1981, 86, 2763-2775. [CrossRef]

20. Hanghoj, K.; Kelemen, P.B.; Hassler, D.; Godard, M. Composition and Genesis of Depleted Mantle Peridotites from the Wadi Tayin Massif, Oman Ophiolite; Major and Trace Element Ge- ochemistryand Os Isotope and PGE Systematics. J. Petrol. 2010, 51, 201-227. [CrossRef]

21. Pallister, J.S.; Knight, R.J. Rare-earth element geochemistry of the Samail ophiolite near Ibra, Oman. J. Geophys. Res. 1981, 86, 2673-2697. [CrossRef]

22. Braun, M.G. Petrologic and Microstructural Constraints on Focused Melt Transport in Dunites and the Rheology of the Shallow Mantle. Ph.D. Thesis, MIT, Boston, MA, USA, 2004; p. 212.

23. Gregory, R.T. Melt percolation beneath a spreading ridge: Evidence from the Semail peridotite, Oman. In Ophiolites and Oceanic Lithosphere; Gass, I.G., Lippard, S.J., Shelton, A.W., Eds.; Geological Society, London, Special Publications: Bath, UK, 1984; Volume 13, pp. 55-62. [CrossRef]

24. LeMee, L.; Girardeau, J.; Monnier, C. Mantle segmentation along the Oman Ophiolite fossil mid-ridge. Nature 2004, 432, 167-172. [CrossRef]

25. Monier, C.; Girardeau, J.; LeMée, L.; Polve, M. Along-ridge petrological segmentation of the mantle in the Oman ophiolite. G-cubed 2006, 7. [CrossRef]

26. Kelemen, P.B.; Koga, K.; Shimizu, N. Geochemistry of gabbro sills in the crust/ mantle transi- tion zone of the Oman ophiolite: Implications for the origin of the oceanic lower crust. Earth Planet. Sci. Lett. 1997, 146, 475-488. [CrossRef]

27. Nicolas, A.; Boudier, F.; Ildefonse, B.; Ball, E. Accretion of Oman and United Arab Emirates ophiolite. Discussion of a new structural map. Mar. Geophys. Res. 2000, 21, 147-179. [CrossRef]

28. Oman Drilling Project. Unpublished Data. 2018. Available online: https://www.omandrilling.ac.uk/ (accessed on 12 February 2020).

29. Mercier, J.C.C.; Nicolas, A. Textures and Fabrics of Upper-Mantle Peridotites as Illustrated by Xenoliths from Basalts. J. Petrol. 1975, 16, 454-487. [CrossRef]

30. Leblanc, M.; Violette, J. Distribution of aluminum-rich and chromium-rich pods in ophiolite peridotites. Econ. Geol. 1983, 78, 293-301. [CrossRef] 
31. Grieco, G.; Merlini, A.; Pedrotti, M.; Moroni, M.; Randrianja, R. The origin of Madagascar chromitites. Ore Geol. Rev. 2014, 58, 55-67. [CrossRef]

32. Banerjee, R.; Ray, D. Mineral Chemistry and Alteration Characteristics of Spinel in Serpentinised Peridotites from the Northern Central Indian Ridge. J. Geol. Soc. India 2015, 86, 41-51. [CrossRef]

33. Tartarotti, P.; Susini, S.; Nimis, P.; Ottolini, L. Melt migration in the upper mantle along the Romanche Fracture Zone (Equatorial Atlantic). Lithos 2002, 63, 125-149. [CrossRef]

34. Borghini, G.; Francomme, J.E.; Fumagalli, P. Melt-dunite interactions at 0.5 and 0.7 GPa: Experimental constraints on the origin of olivine-rich troctolites. Lithos 2018, 323, 44-57. [CrossRef]

35. Winter, J.D. Principles of Igneous and Metamorphic Petrology, 2nd ed.; Pearson: London, UK, 2014; p. 705.

36. Stolper, E. A phase diagram for mid-ocean ridge basalts: Preliminary results and implications for petrogenesis. Contr. Miner. Petrol. 1980, 74, 13-27. [CrossRef]

37. Rospabé, M.; Ceuleneer, G.; Benoit, M.; Abily, B.; Pinet, P. Origin of the dunitic mantle-crust transition zone in the Oman ophiolite: The interplay between percolating magmas and high-temperature hydrous fluids. Geology 2017, 45, 471-474. [CrossRef]

38. Zagrtdenov, N.; Ceuleneer, G.; Rospabé, M.; Borisova, A.; Toplis, M.; Benoit, M.; Abily, B. Anatomy of a chromitite dyke in the mantle/crust transition zone of the Oman ophiolite. Lithos 2018, 312-313. [CrossRef]

39. Suhr, G.N. Melt Migration under Oceanic Ridges: Inferences from Reactive Transport Modelling of Upper Mantle Hosted Dunites. J. Petrol. 1999, 40, 575-599. [CrossRef]

40. Suhr, G.; Hellebrand, E.; Snow, J.E.; Seck, H.A.; Hofmann, A.W. Significance of large, refractory dunite bodies in the upper mantle of the Bay of Islands Ophiolite. G-cubed 2003, 4. [CrossRef]

41. Batanovaa, V.G.; Savelieva, G.N. Melt migration in the mantle beneath spreading zones and formation of replacive dunites: A review. Russ. Geol. Geophys. 2009, 50, 763-778. [CrossRef]

42. Arai, S. An estimation of the least depleted spinel peridotites on the basis of olivine-spinel mantle array. Neues Jahrb. Fiir Mineral. Monatsheft 1987, 8, 347-354.

43. Arai, S. Characterization of spinel peridotites by olivine-spinel compositional relationships: Review and interpretation. Chem. Geol. 1994, 113, 191-204. [CrossRef]

44. Kadoshima, K. Petrological Characteristics of the Mantle Section of the Northern Oman and Lizard ophiolites: An Approach from Insitu Rocks and Detrital Chromian Spinel. Ph.D. Thesis, Kanazawa University, Kanazawa, Japan, 2002.

45. Maaloe, S. Geochemical aspects of permeability controlled partial melting and fractional crystallization. Geochim. Cosmochim. Acta 1982, 46, 43-57. [CrossRef]

46. Sobolev, A.V.; Shimizu, N. The ultradepleted melts and permeability of the oceanic mantle. Dokl. Akad. Nauk 1992, 326, 354-360.

47. Kelemen, P.B.; Braun, M.; Hirth, G. Spatial distribution of melt conduits in the mantle beneath oceanic spreading ridges: Observations from Ingalls and Oman ophiolites. G-cubed 2000, 1. [CrossRef] 